\title{
S100A8 and S100A9 Secreted by Allergens in Monocytes Inhibit Spontaneous Apoptosis of Normal and Asthmatic Neutrophils via the Lyn/Akt/ERK Pathway
}

\author{
In Sik Kim ${ }^{1,2}$, Ji-Sook Lee ${ }^{3}$ \\ ${ }^{1}$ Department of Biomedical Laboratory Science, School of Medicine, Eulji University, Daejeon, Korea \\ ${ }^{2}$ Department of Senior Healthcare, BK21 Plus Program, Graduate School, Eulji University, Daejeon, Korea \\ ${ }^{3}$ Department of Clinical Laboratory Science, Wonkwang Health Science University, Iksan, Korea
}

\section{단구에서 분비되는 S100A8과 S100A9의 Lyn/Akt/ERK 경로를 통한 정상인과 천식질환 호중구의 세포고사 억제 효과}

\author{
김인식 ${ }^{1,2}$, 이지숙 ${ }^{3}$ \\ ${ }^{1}$ 을지대학교 대전캠퍼스 임상병리학과, ${ }^{2}$ 을지대학교 대전캠퍼스 BK21 플러스 프로그램 시니어 헬스케어학과, ${ }^{3}$ 원광보건대학교 임상병리과
}

\begin{abstract}
Der $\mathrm{p} 1$ and Der $\mathrm{p} 2$ are essential allergens of house dust mite associated with the development of asthma. In the present study, we examined whether Der $p 1$ and Der $p 2$ induce a release of S100A8 and S100A9 in monocytes, which are involved in the regulatory mechanism of neutrophil apoptosis. We found that Der p 1 and Der p 2 significantly increased the secretion of S100A8 and S100A9 in normal monocytes. Moreover, S100A8 and S100A9 strongly suppressed the spontaneous apoptosis of normal and asthmatic neutrophils. The inhibitory effect of S100A9 was stronger than that of $\mathrm{S} 100 \mathrm{~A} 8$, and asthmatic neutrophils showed a higher inhibitory effect than normal neutrophils. S100A8 and S100A9 induced activation of Lyn, Akt, and ERK in a time-dependent manner. These findings elucidate the roles of Der $\mathrm{p} 1$ and Der $\mathrm{p} 2$ in the interaction between monocytes and neutrophils, as well as contributing to our knowledge of the pathogenesis of allergic diseases.
\end{abstract}

Key words: Allergen, S100 protein, Monocyte, Neutrophil apoptosis

This is an Open Access article distributed under the terms of the Creative Commons Attribution Non-Commercial License (http://creativecommons.org/licenses/by-nc/4.0) which permits unrestricted non-commercial use, distribution, and reproduction in any medium, provided the original work is properly cited.

Copyright $\odot 2017$ The Korean Society for Clinical Laboratory Science. All rights reserved.
Corresponding author: Ji-Sook Lee

Department of Clinical Laboratory Science,

Wonkwang Health Science University, 501

Iksandae-ro, Iksan 54538, Korea

Tel: 82-63-840-1216

Fax: 82-63-840-1219

E-mail: jslee1216@wu.ac.kr

Received: April 13, 2017 Revised $1^{\text {st. }}$ : May 8, 2017

Revised 2 $2^{\text {nd: }}$ May 8, 2017

Revised $3^{\text {th. }}:$ May 17,2017

Revised 4 ${ }^{\text {th: }}$ : May 29, 2017

Accepted: May 29, 2017

\section{INTRODUCTION}

Allergic diseases including asthma, allergic rhinitis, and allergic conjuctivitis are caused by environmental, genetic, and immunological factors [1,2]. Asthma is an allergic disease characterized by airway obstruction, bronchial inflammation, and allergen-specific IgE. House dust mites were composed of Dermatophagoides pteronissinus and Dermatophagoides farinae, are closely related to asthma pathogenesis [3,4]. Der $\mathrm{p} 1$ and Der $\mathrm{p} 2$ are major allergens of Dermatophagoides pteronissinus. Der p 1 induces cleavage of protease-activated receptor (PAR), which results in allergic inflammation. Der p 1 also facilitates allergen invasion and increases IgE production [5,6]. Der $\mathrm{p}$ 
2, a group II allergen from of Dermatophagoides pteronissinus, elicits an inflammatory process including secretion of cytokine such as IL-4, IL-6, and IL-8, and most asthmatic subjects were sensitized to Der $\mathrm{p} 2[7,8]$.

S100A8 and S100A9 belong to the S100 family proteins and are constitutively expressed in monocytes and neutrophils [9-11]. They play as damage-associated molecular pattern (DAMP) via Toll-like receptor 4 (TLR4) and receptor for advanced glycation endproducts (RAGE), and triggers the pathogenesis of asthma, chronic obstructive pulmonary disease, colitis, rheumatoid arthritis, Alzheimer's disease, and tumor [12,13]. Our reports recently demonstrated that S100A8 and S100A9 induce cytokine secretion, which is involved in regulation of neutrophil apoptosis $[14,15]$.

In this work, we studied the roles of Der $\mathrm{p} 1$ and Der $\mathrm{p}$ 2 in production of S100A8 and S100A9 of normal monocytes, as well as constitutive neutrophil apoptosis of normal and allergic subjects due to S100A8 and S100A9 released by Der $\mathrm{p} 1$ and Der $\mathrm{p} 2$.

\section{MATERIALS AND METHODS}

\section{Reagents}

RPMI 1640 and fetal bovine serum (FBS) were purchased from Life Technologies Inc. (Gaithersburg, MD). Der $\mathrm{p} 1$ and Der $\mathrm{p} 2$ were obtained from INDOOR biotechnologies (Charlottesville, VA, USA). Antibodies against phospho-Lyn and phospho-ERK1/2 were purchased from Cell Signaling Technology (Beverly, MA, USA). Antibodies against phospho-Akt and ERK2 were obtained from Santa Cruz Biotechnology (Santa Cruz, CA, USA). Anti-S100A8 and S100A9 antibodies were obtained from Abnova (Taipei, Taiwan).

\section{Normal and allergic subjects}

Allergic asthma subjects were recruited from Konyang University Hospital. Asthmatic patients had mild to severe symptoms of the disease. The normal subjects had normal lung function, no history of asthma, and did not require medication. This study was approved by the Institutional
Review Board of Eulji University for normal volunteers and by the Institutional Review Board of Konyang University for asthma patients. All participants in this study gave their written informed consent.

\section{Isolation of neutrophils and monocytes, and and cell culture}

Human monocytes and neutrophils were isolated from the peripheral blood of normal and asthmatic subjects using Ficoll-Hypaque (Amersham Phamacia Biotech, Buckinghamshire, UK) gradient centrifugation. CD16 microbeads magnetic cell sorting kit and a monocyte isolation kit II (Miltenyi Biotec, Bergisch Gladbach, Germany) were used for neutrophil and monocyte isolation, respectively. The cells were washed after hypotonic lysis to remove erythrocytes. Neutrophils and monocytes were resuspended at $3 \times 10^{6} / \mathrm{mL}$ and $2 \times 10^{6} / \mathrm{mL}$ in RPMI 1,640 medium with $1 \%$ penicillin-streptomycin and $10 \%$ FBS (Life Technologies, Gaithersburg, MD, USA). This method routinely yielded greater than $97 \%$ neutrophil purity and more than $90 \%$ monocyte purity.

\section{Flow cytometry}

After treatment with Der p 1 or Der p 2, human monocytes were harvested and washed twice with PBS. The cells were then fixed with $100 \mu \mathrm{L}$ of $0.37 \%$ paraformaldehyde solution for $15 \mathrm{~min}$ at room temperature. Following removal of the fixing solution, the cells were added to $100 \mu \mathrm{L}$ of $0.2 \%$ Triton X-100 in PBS and incubated for 3 min. Next, the cells were washed twice with PBS buffer containing $0.5 \%$ BSA, after which non-specific antibody binding was reduced by incubating the cells with normal rabbit IgG. The cells were subsequently separated into new tubes, to which PBS buffer containing anti-S100A8 and anti-S100A9 antibodies was added. Baseline fluorescence was obtained by incubation with normal mouse IgG instead of anti-S100 protein antibodies. After washing three times, the cells were incubated at $4^{\circ} \mathrm{C}$ for 30 min with FITC-conjugated goat anti-mouse IgG (Molecular Probes; Eugene, OR, USA). Finally, the cells were washed and analyzed on a FACSort cytofluorimeter 
(Becton Dickinson). The mean intensity of untreated cells was considered 100\%. Alteration of intracellular S100A8 and S100A9 expression after Der $\mathrm{p} 1$ or Der $\mathrm{p} 2$ stimulation was evaluated as the mean intensity of Der $\mathrm{p} 1$ or Der $\mathrm{p}$ 2 -treated cells/the mean intensity of untreated cells $\times 100$.

\section{Production of recombinant S100A8 and S100A9 proteins}

In our previous report, the cDNA of human S100A8 and S100A9 was cloned into pET28 expression vector (Merck Millipore, Darmstadt, Germany) [16]. Recombinant S100A8 and Millipore.

S100A9 expression was then induced with $1 \mathrm{mM}$ isopropyl $\beta$-D-thiogalactoside in E. coliBL21 (DE3, Merck Millipore) for $4 \mathrm{~h}$ and $16 \mathrm{~h}$ at $37^{\circ} \mathrm{C}$, respectively. Thereafter, the bacteria were centrifuged at 5,000 $\mathrm{g}$ for $10 \mathrm{~min}$ and the pellet was lysed in BugBuster Protein Extraction reagent (Merck Millipore).

\section{Detection of apoptosis}

An annexin V-fluorescein isothiocyanate (FITC) apoptosis detection kit (BD Biosciences, San Diego, CA, USA) was used for detection of neutrophil apoptosis. Isolated neutrophils were incubated with FITC-labeled annexin V and propidium iodide (PI) for $15 \mathrm{~min}$ at room temperature. Apoptotic neutrophils were analyzed using a FACSCalibur flow cytometer with the CellQuest software (BD Bioscience) and reported as the percentage of cells showing annexin V+/PI- and annexin V+/PI+.

\section{Western blotting}

After being stimulated with S100A8 or S100A9, neutrophils were harvested and lysed in a lysis buffer. The homogenate was then centrifuged at 10,000 $\mathrm{g}$ for $1 \mathrm{~min}$ at $4^{\circ} \mathrm{C}$, and the supernatant was collected. The protein samples ( $50 \mu \mathrm{g} /$ /ane) were separated by SDS-polyacrylamide gel electrophoresis. The transferred membranes were incubated with anti-phospho-Lyn, anti-phospho-Akt, and anti-phospho ERK1/2 antibodies and then developed using the enhanced chemiluminescence detection system (Amersham Pharmacia Biotech). The same blot was stripped and reprobed with anti-ERK2 antibodies for use as an internal control.

\section{Statistical analysis}

Data were expressed as the means \pm SD Statistical differences were analyzed using a paired $t$-test for twogroup comparisons and one-way ANOVA for comparison of more than two groups. All analyses were conducted using the SPSS statistical software version 10.0 (SPSS, Chicago, IL, USA), and a $p$-value $<0.05$ was considered to indicate statistical significance.

\section{RESULTS}

\section{Der $\mathrm{p} 1$ and Der $\mathrm{p} 2$ increase the secretion of S100A8 and S100A9 in normal monocytes}

We examined, for the first time, the production of S100A8 and S100A9 due to Der p 1 and Der p 2 in normal monocytes. Treatment with Der p 1 and Der p 2 at the concentrations of $10 \mu \mathrm{g} / \mathrm{mL}$ for $24 \mathrm{~h}$ increased the release of S100A8 and S100A9 of normal monocytes (Figure 1). These results indicate that the effects of house dust mite on cytokine release is associated with Der p 1 and Der p 2.

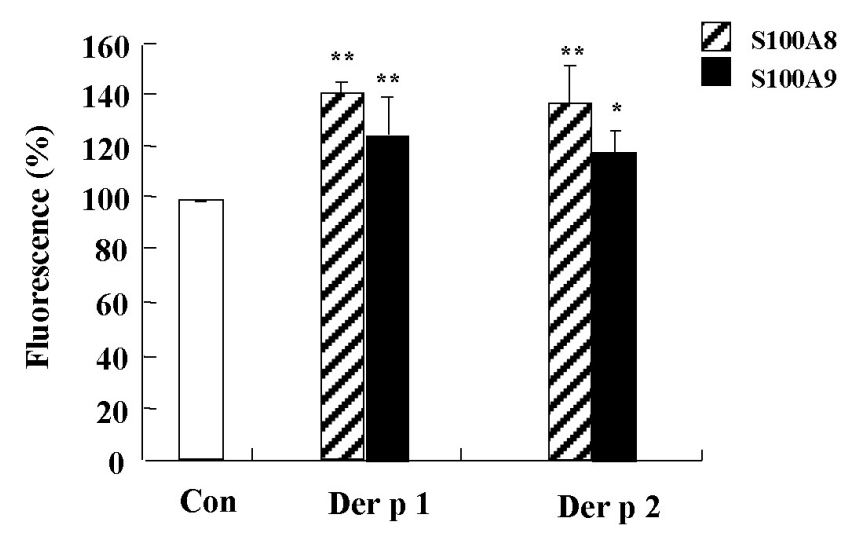

Figure 1. Der $p 1$ and Der $p 2$ increase the secretion of S100A8 and S100A9 in normal monocytes. Monocytes isolated from normal were incubated in the absence or presence of Der $p 1$ or Der $\mathrm{p} 2$ at the concentrations of $10 \mu \mathrm{g} / \mathrm{mL}$ for $24 \mathrm{~h}$, after which the expression of S100A8 and S100A9 was measured by flow cytometry as described in the materials and methods section. 


\section{S100A8 and S100A9 induced by Der $p 1$ and Der $p$}

2 suppress spontaneous apoptosis of normal and allergic neutrophils

Because Der $\mathrm{p} 1$ and Der $\mathrm{p} 2$ increase the expression of S100A8 and S100A9 associated with neutrophil survival, we investigated whether S100A8 and S100A9 inhibit constitutive neutrophil apoptosis or not. As shown in Figure 2 and 3, S100A8 and S100A9 were significantly effective on inhibition of normal and allergic neutrophil apoptosis, despite the different degree of inhibition $(p<$ 0.05). These results indicate that the effect of house dust mite on cytokine secretion of monocytes is involved in inhibition of neutrophil apoptosis.

A

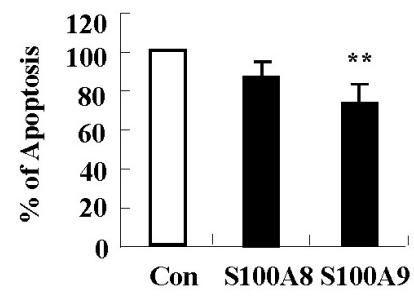

B

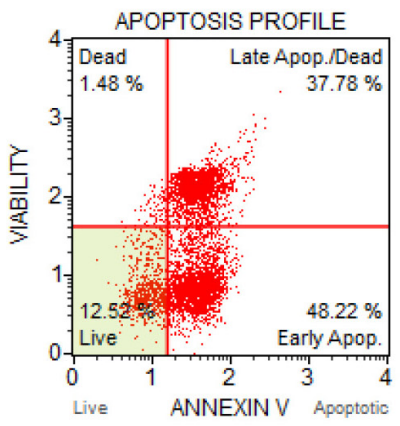

S100A8

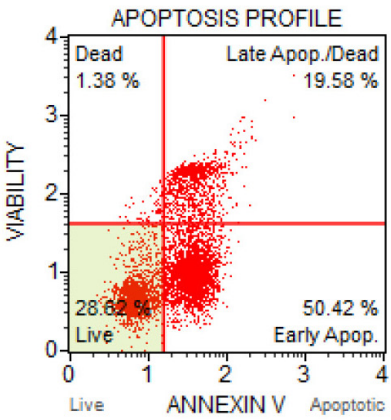

$\mathbf{S 1 0 0 4 9}$

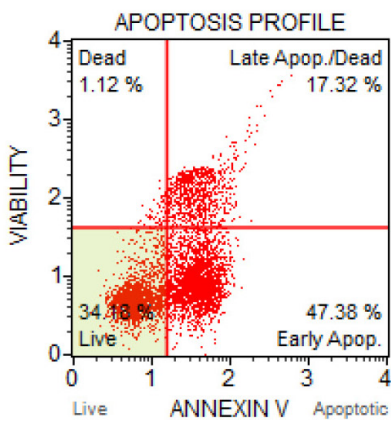

Figure 2. S100A8 and S100A9 induced by Der $\mathrm{p} 1$ and Der $\mathrm{p} 2$ suppress spontaneous apoptosis of normal neutrophils. (A) Normal neutrophils were incubated with $10 \mu \mathrm{g} / \mathrm{mL}$ $\mathrm{S} 100 \mathrm{~A} 8$ or $10 \mu \mathrm{g} / \mathrm{mL}$ S100A9 for $24 \mathrm{~h}$. Apoptosis was analyzed by measuring the binding of annexin V-FITC and PI. Data are expressed as the means \pm SD and are presented relative to the control, which was set at $100 \% .{ }^{*} p<0.05$ and ${ }^{* *} p<0.01$ indicate a significant difference between the control and stimulatortreated groups. (B) Flow cytometry dot plots are presented .

A

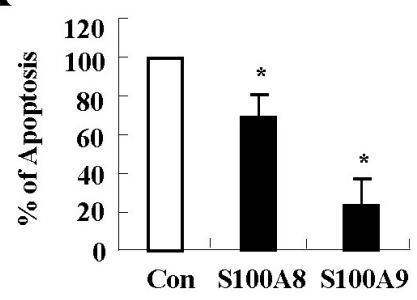

B

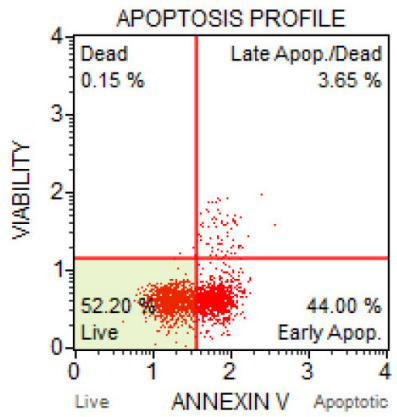

S100A8

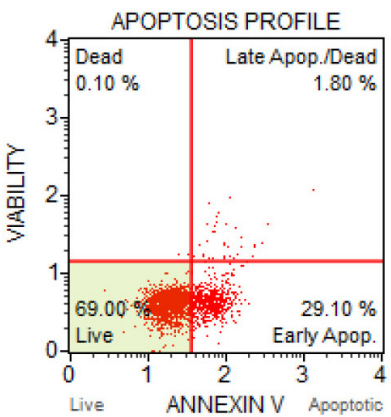

S100A 9

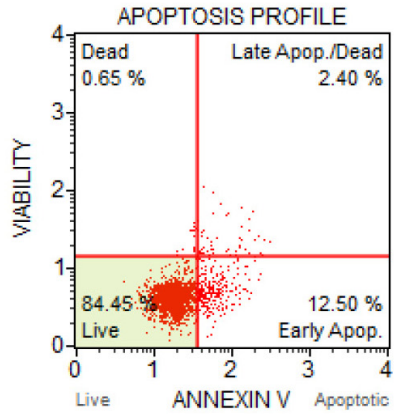

Figure 3. S100A8 and S100A9 induced by Der $\mathrm{p} 1$ and Der $\mathrm{p} 2$ suppress spontaneous apoptosis of asthmatic neutrophils. (A) Asthmatic neutrophils were incubated with $10 \mu \mathrm{g} / \mathrm{mL}$ S100A8 or $10 \mu \mathrm{g} / \mathrm{mL}$ S100A9 for $24 \mathrm{~h}$. Apoptosis was analyzed by measuring the binding of annexin V-FITC and PI. Data are expressed as the means \pm SD and are presented relative to the control, which was set at $100 \% .{ }^{*} p<0.05$ indicates a significant difference between the control and stimulator-treated groups. (B) Flow cytometry dot plots are presented. 


\section{S100A8 and S100A9 have anti-apoptotic effects on neutrophils via Lyn, Akt, and ERK}

Because secretory molecules of monocytes, S100A8 and S100A9, after Der $\mathrm{p} 2$ treatment are involved in neutrophil apoptosis, we investigated the exact anti-apoptotic mechanism of S100A8 and S100A9 in neutrophils. As shown in Figure 4, S100A8 and S100A9 induced the phosphorylation of Lyn, Akt, and ERK in a time-dependent manner. These results indicate that Lyn, Akt, and ERK arre essential signal molecules in inhibitory effects of S100A8 and S100A9 on neutrophil apoptosis.

A

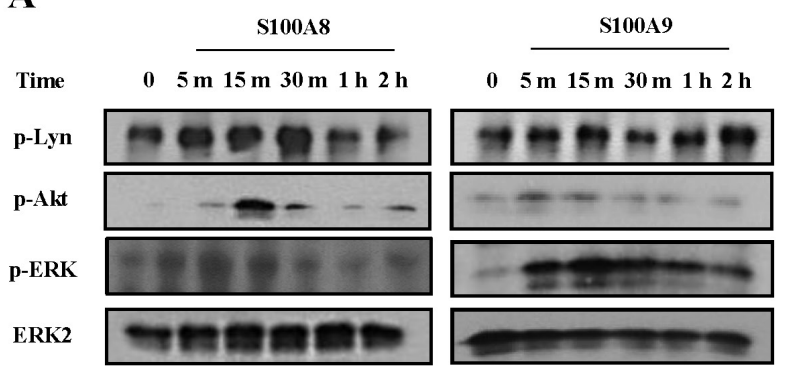

B
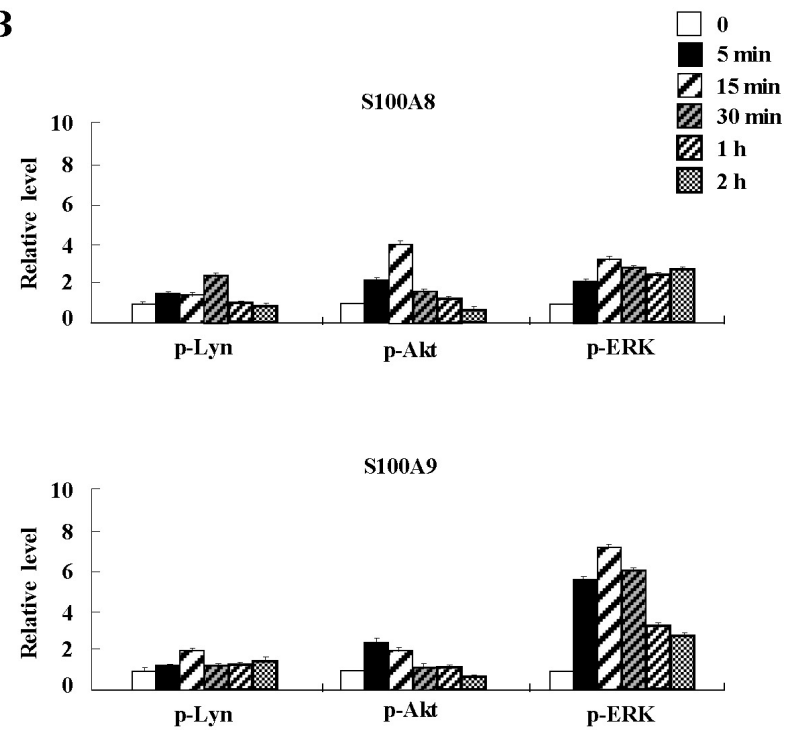

Figure 4. S100A8 and S100A9 have anti-apoptotic effects on neutrophils via Lyn, Akt, and ERK. (A) Normal blood neutrophils were incubated with S100A8 $(10 \mu \mathrm{g} / \mathrm{mL})$ or S100A9 $(10 \mu \mathrm{g} / \mathrm{mL})$ for the indicated time. Phosphorylation of Lyn, Akt and ERK in the lysates was detected by Western blotting. (B) Densitometric data are presented relative to the negative control (lower panel).

\section{DISCUSSION}

House dust mites contain a variety of allergen proteins, which function as cysteine and serine proteases, MD-like molecule, $\alpha$-amylase, and chitinase [17,18]. Der p 1 and Der $\mathrm{p} 2$ are representative allergens and play as important roles in the pathogenesis of asthma [4,19]. We recently demonstrated that S100A8 and S100A9 act as antiapoptotic factors in neutrophils [4]. In the present study, we investigated that Der $\mathrm{p} 1$ and Der $\mathrm{p} 2$ regulate neutrophil apoptosis by inducing the production of S100A8 and S100A9 in monocytes.

Asthma consists of neutrophilic and eosinophilic subtypes, depending on pathological features. Neutrophilic asthma is characterized by a persistence of airway neutrophilia. Dysregulation of neutrophil apoptosis is one of the most important causes in the pathogenesis of neutrophilic asthma [2,20]. As shown in Figures 1-3, Der p 1 and Der p 2 enhanced the secretion of S100A8 and S100A9 in monocytes comparable to the results of our previous report [20]. S100A8 and S100A9 are effective on suppression of neutrophil apoptosis (Figure 2, 3). The constitutive apoptosis of normal and allergic neutrophils is inhibited by lymphocyte activation due to Der $\mathrm{p} 1$ and Der p 2 [16,19]. The activated lymphocytes secret the cytokines such as IL-6, IL-8, MCP-1, and GM-CSF, which were essential inhibitory molecules of neutrophil apoptosis. Taken together, alteration of neutrophil apoptosis may be affected by various cytokines such as IL-6, IL-8, S100A8 and S100A9 secreted by monocytes and lymphocytes. The exact mechanism due to Der $\mathrm{p} 1$ and Der $\mathrm{p} 2$ remains to be elucidated. Further study is needed to examine the Der $\mathrm{p} 1$ and Der p 2-mediated signaling related to $\mathrm{S} 100$ protein expression and anti-apoptotic signaling.

Since S100A8 and S100A9 have inhibitory effects on neutrophil apoptosis, the fact leads us to examine the exact signal mechanism. As shown in Figure 4, S100A8 and S100A9 inhibit neutrophil apoptosis through Lyn, Akt, and ERK. House dust mite regulates neutrophil apoptosis via TLR4, Lyn, PI3K, Akt, ERK, and NF-kB [15,16]. Antiapoptotic signaling mediated by MCP- 1 is involved in the 
$\mathrm{PI3K} / \mathrm{Akt} / \mathrm{ERK} / \mathrm{NF}-\kappa \mathrm{B}$ cascade in normal neutrophils [21] Leptin delays neutrophil apoptosis via ERK/NF- $\kappa$ B pathway [22]. Based on above results, Lyn, Akt, and ERK are essential proteins in suppression of neutrophil apoptosis. Because Der p 1 and Der $\mathrm{p} 2$ are not directly effective on neutrophil apoptosis in normal and asthmatic subjects [16], Der p 1 and Der p 2 indirectly regulate neutrophil apoptosis of normal and asthmatic subjects by increasing S100A8 and S100A9 in monocytes.

\section{요 약}

$\operatorname{Der} \mathrm{p} 1$ 과 Der p 2는 알레르기 질환과 관련된 집먼지 진드기 의 핵심적인 알러젠이다. 본 연구에서는 Der p 1과 Der p 2가 단구에서 S100A8과 S10A9을 분비시키는지를 확인하였고, 분 비된 S100A8과 S10A9이 호중구의 세포고사 조절기전에 작용 하는지를 연구하였다. Der p 1과 Der p 2는 정상인의 단구에서 S100A8과 S10A9을 유의하게 증가시켰고, S100A8과 S10A9 은 정상인과 알레르기 질환 호중구의 자발적 세포고사를 억제 시켰다. 호중구의 Lyn, Akt, ERK는 S100A8과 S10A9을 시간별 로 처리하였을 때 활성화하였다. 본 연구를 통하여 단구와 호중 구에서 Der p 1과 Der p 2의 역할을 규명하였고, 나아가 관련된 알레르기 병인기전을 이해하는데 유용할 것이다.

Acknowledgements: This paper was supported by Wonkwang Health Science University in 2017.

Funding: None

Conflict of interest: None

\section{REFERENCES}

1. Hogate ST. Pathogenesis of asthma. Clin Exp Allergy. 2008; 38(6):872-897.

2. Gaffin, JM, Phipatanakul W. The role of indoor allergens in the development of asthma. Curr Opin Allergy Clin Immunol. 2009;9(2):128-135.

3. Kim IS, Lee JS. Suppressive effect of arazyme on neutrophil apoptosis in normal and allergic subjects. Biomed Sci Lett. 2014;20:244-249.

4. Kim IS, Lee NR, Lee JS. Der p 1 inhibits spontaneous neutrophil apoptosis by cytokine secretion of normal and allergic lymphocytes. Korean J Clin Lab Sci. 2015;47:230-236.

5. Ghaemmaghami AM, Robins RA, Gough L, Sewell HF, Shakib F. Human $\mathrm{T}$ cell subset commitment determined by the intrinsic property of antigen: the proteolytic activity of the major mite allergen Der $\mathrm{p} 1$ conditions $\mathrm{T}$ cells to produce more IL-4 and less IFN- $\gamma$. Eur J Immunol. 2001;31(4):1211-1216.

6. Ghaemmaghami AM, Gough L, Sewell HF, Shakib F. The proteolytic activity of the major dust mite allergen Der $\mathrm{p} 1$ conditions dendritic cells to produce less interleukin-12: allergen-induced Th2 bias determined at the dendritic cell level. Clin Exp Allergy. 2002;32(10):1468-1475.

7. Yu SJ, Liao EC, Sheu ML, Chang DT, Tsai JJ. Cell-penetrating peptide derived from human eosinophil cationic protein inhibits mite allergen Der p 2 induced inflammasome activation. PLoS One. 2015;10:e0129187.

8. Tsai J1, Shen HD, Chua KY. Purification of group 2 Dermatophagoides pteronyssinus allergen and prevalence of its specific IgE in asthmatics. Int Arch Allergy Immunol. 2000;121(3): 205-210.

9. Goyette J, Geczy CL. Inflammation-associated S100 proteins: new mechanisms that regulate function. Amino Acids. 2011; 41(4):821-842.

10. Kerkhoff Cl, Voss A, Scholzen TE, Averill MM, Zänker KS, Bornfeldt KE. Novel Insights into the role of S100A8/A9 in skin biology. Exp Dermatol. 2012;21(11):822-826.

11. Nam AR, Kim DH, Kim MJ, Lee JS, Yang SJ, Kim IS. S100A8 induces secretion of MCP-1, IL-6, and IL-8 via TLR4 in Jurkat T cells. Biomed Sci Lett. 2016;22:60-64.

12. Gebhardt C, Németh J, Angel P, Hess J. S100A8 and S100A9 in inflammation and cancer. Biochem Pharmacol. 2006;72(11): 1622-1631.

13. Chen B, Miller AL, Rebelatto M, Brewah Y, Rowe DC, Clarke L, et al. S100A9 induced inflammatory responses are mediated by distinct damage associated molecular patterns (DAMP) receptors in vitro and in vivo. PLoS One. 2015;10:e0115828.

14. Kim EH, Lee JS, Lee NR, Baek SY, Kim EJ, Lee SJ, et al. Regulation of constitutive neutrophil apoptosis due to house dust mite allergen in normal and allergic rhinitis subjects. PLoS One. 2014;9:e105814.

15. Lee NR, Baek SY, Gu A, Kim DH, Kim SY, Lee JS, et al. House dust mite allergen suppresses neutrophil apoptosis by cytokine release via PAR2 in normal and allergic lymphocytes. Immunol Res. 2016;64(1):123-132.

16. Kim DH, Choi E, Lee JS, Lee NR, Baek SY, Gu A, et al. House dust mite allergen regulates constitutive apoptosis of normal and athmatic neutrophils via Toll-Like Receptor 4. PLoS One. 2015;10:e0125983

17. Lee JS, Chooi E, Yang EJ, Lee NR, Baek SY, Kim EJ, et al. Induction of the neutrophil migration in normal subjects due to asthmatic bronchoalveolar lavage fluid (BALF). Biomed Sci Lett. 2014;20:1-6.

18. Thomas WR, Hales BJ, Smith WA. House dust mite allergens in asthma and allergy. Trends Mol Med. 2010;16(17):321-328.

19. Kim IS, Lee NR, Lee JS. Suppressive effect of Der p 2 on constitutive neutrophil apoptosis by cytokine secretion of normal and allergic lymphocytes. Korean J Clin Lab Sci. 2016;48:102108.

20. Kim IS, Kim EH, Kim DH, Kim JS, Lee JS. Effect of house dust mite and CCL2 on S100A8 and S100A9 expression in human monocytes. Biomed Sci Lett. 2013;19: 344-347.

21. Yang EJ, Choi E, Ko J, Kim DH, Lee JS. Differential effect of 
134 In Sik Kim and Ji-Sook Lee. Anti-apoptotic Effect of S100A8 and S100A9 Secreted by Mites on Neutrophil Apoptosis

CCL2 on constitutive neutrophil apoptosis between normal and asthmatic subjects. J Cell Physiol. 2012;227(6):2567-2577.

22. Sun Z, Dragon S, Becker A, Gounni AS. Leptin inhibits neu-

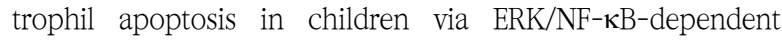
pathways. PLoS One. 2013;8(1):e55249. 